\title{
Pengaruh Motivasi Belanja Hedonis, Gaya Hidup Berbelanja dan Promosi Penjualan terhadap Pembelian Impulsif pada Konsumen Shopee ID
}

\author{
Muhammad Afif ${ }^{1}$ \\ Program Studi Manajemen, STIE Kertanegara Malang \\ afifm0101@gmail.com \\ Purwanto $^{2}$ \\ Program Studi Manajemen, STIE Kertanegara Malang \\ purwantoa666@gmail.com
}

\begin{abstract}
This research was conducted on Shopee ID consumers (Studies in STIE Kertanegara Malang Students). The purpose of this research is to find out the influence of hedonic shopping motivation, shopping lifestyle and sales promotions on impulsive purchases on Shopee ID consumers. The method used is quantitative by collecting, presenting and analyzing data from Shoopee ID consumers using a questionnaire to respondents. Data analysis technique in this research is multiple linear regression to determine the effect simultaneously, partially and dominantly. Based on the results of the study, the influence of hedonic shopping motivation, shopping lifestyles and sales promotions on impulsive purchases on Shopee ID consumers was simultaneously significant (0.00). The influence of hedonic shopping motivation, shopping lifestyle and sales promotion on impulsive purchases on Shopee ID consumers is partially significant $X 1(0.00), X 2(0.03)$ and $X 3$ (0.03). Hedonic shopping motivation are influenced by indicators such as : adventure, social, idea. value and status.
\end{abstract}

Keywords : hedonic shopping motivation, shopping lifestyle, sales promotion, impulsive buying

\section{ABSTRAK}

Penelitian ini dilakukan pada konsumen Shopee ID (Studi pada Mahasiswa STIE Kertanegara Malang). Tujuan penelitaian ini adalah untuk mengetahui pengaruh motivasi belanja hedonis, gaya hidup berbelanja dan promosi penjualan terhadap pembelian impulsif pada konsumen Shopee ID. Metode yang digunakan berupa kuantitatif yaitu dengan cara mengumpulkan, menyajikan dan menganalisis data dari konsumen Shopee ID menggunakan kuesioner kepada responden. Teknik analisis data dalam penelitian ini yaitu regresi linier berganda untuk mengetahui pengaruh secara simultan, parsial dan dominan. Berdasarkan hasil penelitian, pengaruh motivasi belanja hedonis, gaya hidup berbelanja dan promosi penjualan terhadap pembelian impulsif pada konsumen Shopee ID secara simultan signifikan (0.00). Pengaruh motivasi belanja hedonis, gaya hidup berbelanja dan promosi penjualan terhadap pembelian impulsif pada konsumen Shopee ID secara parsial signifikan X1 (0.00), X2 (0.03) dan X3 (0.03). Diantara pengaruh motivasi belanja hedonis, gaya hidup berbelanja dan promosi penjualan terhadap pembelian impulsif pada konsumen Shopee ID yang paling dominan adalah motivasi belanja hedonis. Pada motivasi belanja hedonis dipengaruhi oleh indikator antara lain : petualangan, sosial, ide, nilai dan status.

Kata Kunci : Motivasi belanja hedonis, gaya hidup berbelanja, promosi penjualan, pembelian impulsif 


\section{Pendahuluan}

Perkembangan teknologi komunikasi dan informasi semakin pesat. Hal tersebut tidak lepas dari peranan internet yang menjadi media dalam berkomunikasi. Masyarakat yang dapat saling terhubung ke seluruh dunia sehingga pertukaran informasi mulai dari proses penyampaian sampai penerimaan informasi dapat terjadi secara global sehingga internet menjadi kebutuhan bagi masyarakat. Penggunaan internet di Indonesia mengalami peningkatan yang cukup signifikan pada setiap tahunnya. Menurut data Asosiasi Penyelenggara Internet Indonesia, pengguna internet pada tahun 2018 mencapai 171,17 juta jiwa $(64,8 \%)$ dari jumlah penduduk di Indonesia yang sebanyak 264 juta jiwa. (sumber : ZONAUTARA.com 16 Mei 2019).

\section{Gambar. 1 Pertumbuhan Pengguna Internet di Indonesia}

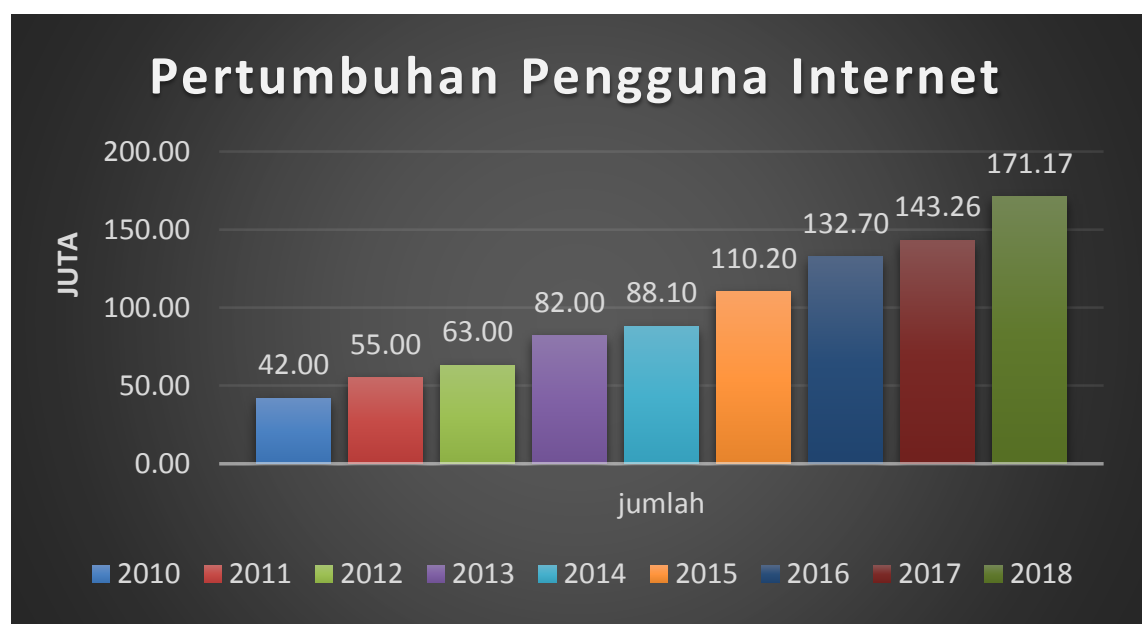

Sumber : APJI 2019, diakses dari zonautara.com 16 Mei 2019

Seiring dengan Tingginya pertumbuhan pengguna internet di Indonesia menimbulkan perubahan perilaku terutama dalam pola berbelanja. Masyarakat lebih cenderung memilih berbelanja secara online dibanding secara konvensional. Data bank Indonesia menyebutkan, transaksi toko online di Indonesia sepanjang sepanjang 2018 lalu mencapai Rp. 77,766 triliun yang mengalami peningkatan sebanyak $151 \%$ dibandingkan tahun sebelumnya yang hanya mencapai Rp. 30,942 triliun. (sumber CNBC indonesia Tech 11 march 2019 10:29).

Peningkatan penjualan berbasis Bussines to Customer menjadi bukti berkembangnya e commerce di Indonesia. Berdasarkan data yang dipublikasi oleh Databoks.co.id (2019) menunjukkan bahwa terjadi peningkatan pengguna dan penetrasi $e$ commerce di Indonesia dari tahun ke tahun. Berikut grafik kenaikan nilai transaksi $e$ commerce di Indonesia mulai tahun 2017 : 


\section{Gambar. 2 Pengguna dan penetrasi e commerce di Indonesia}

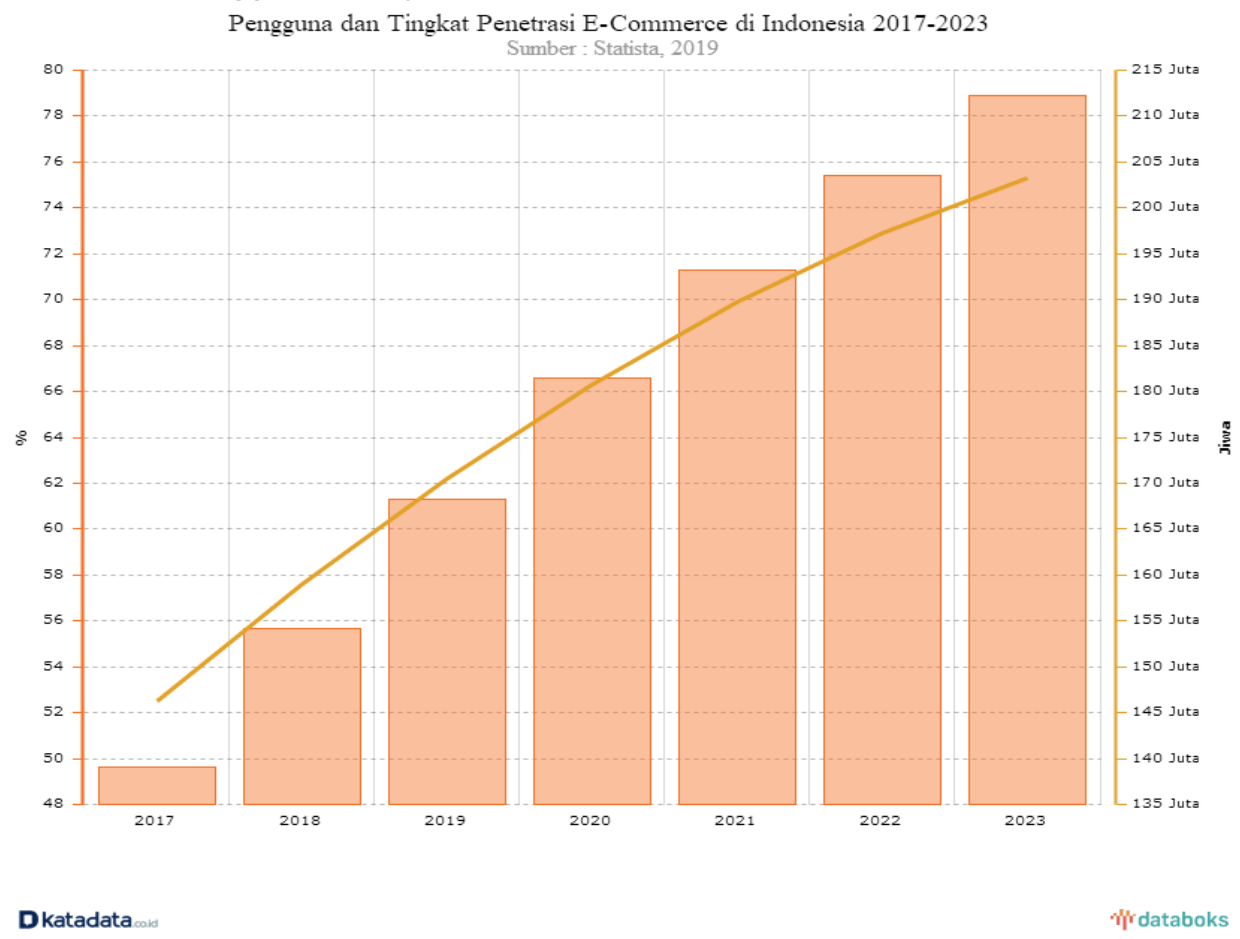

\section{Sumber : Statista 2019}

Berdasarkan data yang dipublikasi oleh katadata.co.id jumlah pengguna e-commerce di Indonesia pada 2017 mencapai 139 juta pengguna, kemudian naik 10,8\% menjadi 154,1 juta pengguna di tahun lalu. Tahun ini diproyeksikan akan mencapai 168,3 juta pengguna dan 212,2 juta pada 2023. Semakin berkembangnya bisnis berbasis online ini diharapkan dapat membuat perusahaan e commerce untuk dapat menetukan strategi yang tepat agar dapat menarik perhatian konsumen. Menurut Peter dan Olson (2013,p.163) karena konsumen sebagai pengambil keputusan pembelian, maka pengetahuan tentang perilaku pengambilan keputusan konsumen perlu diketahui para pelaku usaha untuk meningkatkan intensitas pembelian produk atau jasa yang dijual. Dengan demikian sebelum menarik hati konsumen, hal pertama yang perlu dilakukan adalah memahami perilaku pembelian konsumen.

Dalam setiap transaksi pembelian yang dilakukan melalui aplikasi belanja online, tanpa disadari ada beberapa konsumen yang membeli sebuah produk yang tidak mereka rencanakan atau inginkan sebelumnya. Fenomena seperti ini sering disebut sebagai impulse buying atau pembelian impulsif. Pada perilaku pembelian ini konsumen akan mengalami keinginan yang kuat untuk membeli sesuatu dengan segera. Impulsif untuk membeli merupakan hal yang sangat kompleks akan menstimulasi konflik emosional. Pembelian juga cenderung dilakukan dengan mengabaikan pertimbangan atau konsekuensinya (Utami,2012,p.67). Penelitian ini berfokus pada perilaku pembelian impulsif yang dipengaruhi oleh motivasi belanja hedonis, gaya hidup berbelanja dan promosi penjualan. Motivasi belanja hedonis akan tercipta dengan adanya gairah berbelanja seseorang yang terpengaruh model terbaru dan belanja menjadi gaya hidup seseorang untuk memenuhi kebutuhan sehari-hari. Menurut Park, Kim dan Forney (2006), motivasi belanja hedonis memiliki peran penting dalam pembelian impulsif, karena motivasi 
belanja hedonis menjadi pendorong konsumen untuk suka terhadap suatu produk, senang dan juga karena pengaruh emosional. Motivasi belanja hedonis dipandang sebagai pengalaman positif yang memuaskan konsumen secara emosional terkait dengan aktivitas berbelanja terlepas dari apakah konsumen melakukan pembelian atau tidak karena konsumen tidak bertujuan mencari manfaat dari suatu produk tetapi kesenangan saat proses berbelanja yang menjadi tujuannya. Alasan seseorang memiliki sifat hedonis karena banyak kebutuhan yang tidak dapat terpenuhi sebelumnya kemudian setelah kebutuhan tersebut terpenuhi maka akan muncul kebutuhan yang lebih tinggi dari sebelumnya. Hal ini dapat disimpulkan bahwa motivasi belanja hedonis salah faktor utama penyebab impulse buying.

Shopee merupakan e commerce yang memiliki peningkatan paling signifikan dengan penambahan pengunjung hingga 16 juta. Shopee pada kuartal ke 3 ini berhasil menduduki peringkat kedua dengan menguasai 21 persen market share. Menurut laporan iprice, rataan pengunjung website shopee pada Q3 2019 ini adalah 55.964.700. Pencapaian tersebut tidak lepas dari transaksi pada kota-kota besar yang beberapa diantaranya bersifat impulsif terutama terjadi pada kaum muda. Salah satunya adalah kota Malang yang memiliki banyak Universitas negeri maupun swasta selalu menjadi pilihan kaum muda pendatang untuk mengenyam pendidikan tak terkecuali STIE Kertanegara Malang. Peneliti memilih mahasiswa STIE Kertanegara Malang sebagai konsumen potensial untuk dijadikan subjek penelitian, karena mayoritas dari mereka usia 19 sampai 25 tahun intens melakukan pembelian secara online. Hal ini terbukti dari hasil survey pendahuluan yang telah dilakukan oleh peneliti menunjukkan bahwa dari 35 mahasiswa $85,7 \%$ merupakan pengguna aplikasi belanja Shopee. Dari hasil pra riset 5,7\% pembeli impulsif murni, $40 \%$ pembeli semi impulsif dan 54,3\% merupakan pembeli yang membuat rencana terlebih dahulu. Dari data tersebut dapat ditarik kesimpulan bahwa sebanyak 54,3\% konsumen tidak tertarik dengan stimulus oleh Shopee Indonesia sehingga mereka tidak melakukan pembelian impulsif. Tingkat pembelian impulsif pada Mahasiswa STIE Kertanegara Malang masih kurang. Maka dari itu, peneliti membuat rumusan masalah untuk menjawab pertanyaan :

1) Apakah terdapat pengaruh motivasi belanja hedonis, gaya hidup berbelanja dan promosi penjualan secara simultan terhadap pembelian impulsif pada konsumen Shopee ID?

2) Apakah terdapat pengaruh motivasi belanja hedonis, gaya hidup berbelanja dan promosi penjualan secara parsial terhadap pembelian impulsif pada konsumen Shopee ID ?

3) Diantara manakah variabel motivasi belanja hedonis, gaya hidup berbelanja dan promosi penjualan yang paling dominan berpengaruh terhadap pembelian impulsif pada konsumen Shopee ID ?

\section{A. Motivasi belanja hedonis}

Motivasi dapat digambarkan sebagai tenaga pendorong dalam diri individu yang memaksa mereka untuk bertindak (Schiffman dan Kanuk, 2008). Keadaan tertekan merupakan sebuah pendorong yang timbul akibat kebutuhan yang tidak dapat terpenuhi. Dalam memenuhi kebutuhan setiap orang membutukkan dorongan dan keinginan. Oleh karena itu motivasi merupakan sebuah faktor pendukung setiap orang dalam melakukan suatu tindakan.

Hedonis berasal dari bahasa Yunani yang artinya kenikmatan atau kesenangan (Yistiani, 2012 dalam Utami 2016). Bagaimanapun cara, apapun sarananya, apapun akibatnya dan aktivitas yang dilakukan semuanya diarahkan demi kesenangan. Menurut Susianto dalam Paramitha et al (2014) seseorang yang memiliki pola hidup hedonis selalu hedonis selalu ingin menjadi pusat perhatian dan untuk menghindari kesengsaraan dengan memiliki fasilitas yang berkecukupan. 
Shopping merupakan aktivitas untuk membeli sesuatu yang dalam bahasa Indonesia disebut sebagai berbelanja. Motivasi belanja hedonis merupakan motivasi atau keinginan konsumen untuk berbelanja karena berbelanja merupakan suatu kesenangan tersendiri sehingga tidak memeperhatikan manfaat dari produk yang dibeli (Utami, 2010,p.47). Menurut Semuel (2005) perilaku hedonic shopping adalah gambaran instrumen yang menyajikan secara langsung manfaat dari suatu pengalaman berbelanja seperti halnya kesenangan, perilaku hedonis direflesikan sebagai nilai intrinsik yang menggambarkan pengalaman individu dalam berbelanja.

Lestari dan Utomo (2014) mengatakan bahwa aspek hedonis berkaitan dengan emosional konsumen, sehingga ketika berbelanja konsumen benar-benar merasakan sesuatu seperti senang, benci, marah ataupun merasa bahwa berbelanja merupakan suatu petualangan. Menurut Scrapi (2006) motivasi belanja hedonis menggambarkan nilai pengalaman berbelanja meliputi fantasi, sensor, rangsangan, kegembiraan, kesenangan, keingintahuan dan khayalan kegembiraan.

\section{B. Gaya Hidup Berbelanja}

Secara sederhana gaya hidup dapat diartikan tentang bagaiman cara seseorang dalam hidup. Menurut Levy \& Weitz (2009) shopping lifestyle adalah gaya hidup yang mengacu tentang bagaimana seseorang hidup, bagaimana mereka menghabiskan uang, waktu, melakukan pembelian, pendapat dan sikap tentang dunia dimana mereka tinggal. Seseorang menjadikan gaya hidupnya sebagai status sosial, karakteristik dan sifat bagi seorang individu. Gaya hidup menyediakan pandangan kehidupan sehari-hari dari seorang konsumen secara luas atau digunakan sebagai segmentasi pasar (Aziz \& V, 2015).Jika memahami gaya hidup konsumen ada beberapa manfaat yang didapatkan oleh pemasar antara lain pemasar dapat menggunakan gaya hidup konsumen untuk melakukan segmentasi konsumen, pemasar dapat menempatkan produk dimedia yang sesuai, membantu mempromosikan produknya dipasar dengan menggunakan iklan dan pemasar juga dapat mengolah produknya sesuai dengan keinginan atau gaya hidup konsumen.

Menurut Betty Jackson (2004) shopping lifestyle merupakan sebuah ekspresi tentang gaya hidup dalam berbelanja yang menggambarkan perbedaan strata sosial. Cara dalam berbelanja menggambakan martabat, status dan kebiasaan. Gaya hidup tersebut termasuk dalam kategori fashion/pakaian. Menurut Kotler $(2007, p .225)$ life style merupakan pola hidup seseorang di dunia yang terungkap pada aktivitas, opini dan minat seseorang. Minat manusia dalam berbagai barang yang mereka beli mencerminkan gaya hidup tersebut.Cobb dan Hoyer $(1986$, p.524) menyatakan "Shopping lifestyle is defined as the behavior exhibited by purchaser with regard to the series of personal responses and opinion about purchases of the products ". Pendapat tersebut memiliki arti bahwa gaya hidup berbelanja merupakan perilaku yang ditunjukkan oleh pembelanja memperhatikan pada respon personal dan opini atas pembelian produk. Gaya hidup berbelanja setiap orang tentunya berbeda-beda. Hal yang membedakan adalah cara hidup seseorang untuk mengekspresikan diri dengan orang lain melalui gaya berbelanja.

Perubahan gaya hidup yang semakin berkembang dapat menimbulkan konsumen untuk mengikuti perkembangan. Gaya hidup life style dapat dipengaruhi oleh kebutuhan konsumen. Kegiatan shopping menjadi solusi terbaik bagi seseorang untuk memenuhi kebutuhan hidupnya. Adakalanya kegiatan shopping disebabkan oleh pola konsumsi seseorang untuk menghabiskan waktu, uang dan berbelanja menjadi sebuah 
gaya hidup. Sehingga shopping lifestyle ini menjadi penyebab timbulnya pembelian secara impulsif (Kosyu, 2014).

\section{Promosi Penjualan}

Menurut Kotler dan Keller (2012,p.519) promosi penjualan atau sales promotion merupakan berbagai alat insentif, yang sebagian besar berjangka pendek, yang dirancang untuk merangsang pembelian produk atau jasa tertentu dengan lebih cepat dan lebih besar oleh konsumen atau pedagang. Definisi lain yang diungkapkan oleh Belch $(2015$, p.529) promosi penjualan adalah aktivitas pemasaran yang menyediakan nilai tambah atau insentif kepada tenaga penjual (sales force), distributor atau pelanggan utama dengan tujuan utama yaitu dapat menstimulasi penjualan secara cepat. Tujuan akhir dari promosi penjualan adalah untuk menarik konsumen agar dapat membeli produk dan mendapatkan profit yang sebesar-besarnya. Menurut Kotler dan Keller (2009,p.219), iklan menawarkan alasan untuk membeli, sedangkan promosi penjualan menawarkan insentif untuk membeli.

Menurut Belch (2015,p.521) ada beberapa alat untuk promosi penjualan yang berorientasi pada konsumen untuk merangsang pembelian konsumen, antara lain :

1) Couponing

Sebuah cara yang digunakan konsumen agar mendapatkan penghematan dalam bentuk kode voucher agar dapat melakukan pembelian tertentu.

2) Free premium gifts

Suatu bentuk rangsangan yang bertujuan agar konsumen membeli barang yang ditawarkan dalam bentuk memberikan hadiah yang berupa barang secara gratis.

3) Cash refund refund (rabates)

Suatu bentuk penawaran untuk mengembalikan sebagian dari harga dalam sebuah pembelian.

4) Bonus pack.

Sebuah metode promosi yang memberikan tambahan dari produk dengan memberikan unit tambahan atau kemasan yang lebih besar.

5) Price of deals

Sebuah promosi yang memberikan potongan harga pada suatu produk secara langsung dala waktu tertentu.

6) Loyalty program

Suatu metode promosi yang dilakukan dengan memberikan hadiah kepada pelanggan yang telah menggunakan produk dalam jangka waktu yang lama.

7) Event marketing

Sebuah metode promosi dimana sebuah peusahaan dihubungkan dengan suatu acara tertentu sebagai sponsor dengan tujuan menciptakan pengalaman khusus bagi konsumen serta mempromosikan suatu produk atau jasa.

\section{Pembelian Impulsif}

Berdasarkan dengan perencanaan, perilaku pembelian dibagi menjadi dua yaitu pembelian terencana (Planned Phurchasing) dan pembelian tak terencana (impulse buying behaviour atau unplanned phurchasing). Pembelian terencana merupakan pembelian yang telah menetapkan item yang akan dibeli sebelum memasuki toko, sedangkan pembelian tidak terencana adalah perilaku pembelian dimana konsumen tidak mempertimbangkan untuk membeli atau mempertimbangkan untuk membeli tapi 
belum memutuskan produk apa yang akan dibeli atau bisa diartikan sebagai tindakan membeli yang tanpa memiliki masalah sebelumnya atau niat membeli sebelum memasukit toko (Mowen \& Minor,2002,p.65). Lain halnya yang diungkapkan oleh Piron $(1991$, p.512) bahwa pembelian yang tidak terencana, sebagai hasil dari suatu terpaan akan stimulus dan diputuskan ditempat. Setelah melakukan pembelian, konsumen akan mengalami reaksi emosional dan atau kognitif

Berman (2010,p.207) menuturkan bahwa impulse buying ini timbul saat konsumen membeli produk atau merek yang tidak mereka rencanakan ketika memasuki toko, membaca surat atau katalog, melihat acara TV belanja, belanja online dan sebagainya. Hal ini berarti pembelian impulsif terjadi secara spontan dan tidak ada planning atau rencana untuk membeli produk sebelumnya akan tetapi dorongan untuk membeli terjadi setelah memasuki toko, melihat katalog dan juga setelah melakukan browsing di situs belanja online.

Menurut Stern dalam Utami ( 2014,p.68) menjelaskan bahwa ada empat tipe pembelian impulsif yaitu :

1) Impulsif murni

Pembelian ini mengacu pada tindakan membeli sesuatu karena alasan menarik, biasanya terjadi karena adanya loyalitas terhadap merk atau pembelian yang sudah biasa dilakukan. Contoh membeli sepatu merek Krisbow bukan membeli sepatu merek Kings seperti biasanya.

2) Impulse pengingat

Pembelian pada jenis ini mengacu pada unit yang biasanya dibeli tetapi tidak tercatat pada daftar belanja contohnya ketika seseorang sedang melakukan antrian di toko obat, konsumen melihat aspirin pada rak dan ingat bahwa persediaan di rumahnya akan habis, sehingga penglihatan tersebut memicu pembelian yang tidak terencana.

3) Impulse saran

Pembelian pada tipe ini terjadi ketika konsumen menemukan suatu produk untuk pertama kali dan menstimulasi keinginan untuk mencoba produk tersebut. Contohnya seorang ibu rumah tangga melihat produk penyedap rasa makanan disebuah toko, hal ini secara langsung mereleasikan produk tersebut didasarkan atas pertimbangan tentang tambahan penyedap rasa makanan karena aktivitas memasak didalam rumah dan kemudian membelinya.

4) Impulse terencana

Pada pembelian ini terjadi karena adanya respon konsumen terhadap beberapa insentif spesial untuk membeli unit yang tidak diantisipasi. Impulsif ini biasanya terjadi karena adanya pengumuman penjualan kupon, potongan kupon dan penawaran menggiurkan lainnnya. 


\section{E. Kerangka Konseptual Penelitian}

\section{Gambar3. Pengguna dan penetrasi e commerce di Indonesia}

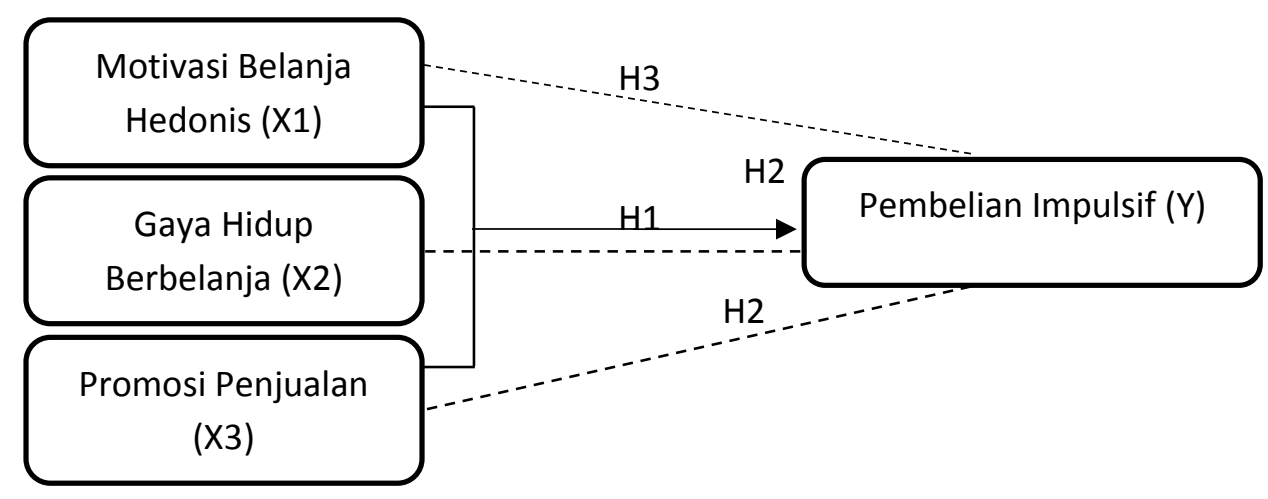

Sumber : Data penelitian diolah

Berdasarkan kerangka konseptual penelitian yang telah diuraikan, maka hipotesis sebagai berikut :

$\mathrm{H} 1=$ Diduga motivasi belanja hedonis, gaya hidup berbelanja dan promosi penjualan berpengaruh secara simultan terhadap pembelian impulsif pada konsumen Shopee ID.

$\mathrm{H} 2=$ Diduga motivasi belanja hedonis, gaya hidup berbelanja dan promosi penjualan berpengaruh secara parsial terhadap pembelian impulsif pada konsumen Shopee ID.

$\mathrm{H} 3=$ Diduga motivasi belanja hedonis paling dominan berpengaruh diantara variabel motivasi belanja hedonis, gaya hidup berbelanja dan promosi penjualan terhadap pembelian impulsif pada konsumen Shopee ID.

\section{Metode Penelitian}

\section{A. Instrument Penelitian.}

Menurut Sugiyono (2012:92) instrumen penelitian akan digunakan untuk melakukan pengukuran dengan tujuan menghasilkan data kuantitatif yang akurat. Instrumen penelitian merupakan alat atau fasilitas yang digunakan oleh peneliti dalam mengumpulkan data agar pekerjaannya lebih mudah dan hasilnya lebih baik dengan kata lain mudah diolah serta sistematis dan lengkap (Arikunto,2010:173). Instrumen yang digunakan dalam penelitian ini berupa kuisioner yang berisikan pernyataan yang merupakan tanggapan dari para responden. Responden tidak perlu memberikan jawaban yang panjang karena sudah disediakan jawaban yang sudah disusun secara terbatas oleh peneliti.

Penelitian ini menggunakan skala Likert sebagai teknik penilaian. Skala Likert merupakan skala psikometrik yang paling banyak digunakan dalan riset dan yang umum dipakai dalam angket atau kuisioner yang berupa survei. Jawaban dari pernyataan yang diberikan menggunakan sistem berupa skor angka 1 sampai 5, sebagai berikut : 
1) Sangat Setuju (SS) $=5$

2) Setuju (S) $=4$

3) Ragu-ragu (R) $=3$

4) Tidak Setuju (TS) $=2$

5) Sangat Tidak Setuju (STS) $\quad=1$

\section{B. Uji Validitas}

Validitas merupakan suatu ukuran yang menunjukkan bahwa variabel yang diukur memang benar-benar variabel yang hendak diteliti oleh peneliti (cooper dan Schindler dalam Zulganef 2006). Uji ini digunakan untuk mengukur valid atau tidak sebuah kuisioner. Jika $r$ hitung $>r$ tabel maka instrumen atau pernyataan memiliki korelasi terhadap skor total dinyatakan valid. Menguji tiap instrumen valid tidaknya dapat dilihat dalam tampilan hasil Cronbach Alpha pada kolom Corected Item Total Correction. Tujuan perhitungan untuk mendapatkan korelasi $(r)$ yang dibandingkan dengan signifikan $95 \%$ atau $a=5 \%$. Uji validitas ini menggunakan software IBM SPSS 25 statistics for windows.

\section{Uji Realibilitas}

Menurut Azwar (2009) uji realibilitas merupakan penerjemah dari kata-kata yang artinya kepercayaan, keterandalan, konsistensi dan sebagainya. Fungsi dari uji realibilitas adalah untuk mengetahui ketepatan dan keakuratan sebuah instrumen. Dalam Penelitian ini peneliti menggunakan metode Cronbach Alpha dalam menguji apakah setiap instrumen realibel atau tidak. Variabel dikatakan realibel jika memberikan nilai cronbach alpha > 0,70 meskipun nilai 0,60 masih dapat diterima (Ghozali,2011). Uji realibilitas ini menggunakan software IBM SPSS 25 statissics for windows.

\section{Analisis Regresi Linier Berganda}

Teknik analisis untuk mengetahui pengaruh variabel independen terhadap variabel dependen, model dalam penelitian ini adalah :

$$
Y=\alpha+\beta 1 X 1+\beta 2 X 2+\beta 1 X 3+e
$$

$\begin{array}{ll}\text { Keterangan : } & \\ Y & =\text { Pembelian Impulsif } \\ \alpha & =\text { Konstanta } \\ \beta 1-\beta 3 & =\text { Koefisien regresi } \\ \text { X1 } & =\text { Motivasi Belanja Hedonis } \\ \text { X2 } & =\text { Gaya Hidup Berbelanja } \\ \text { X3 } & =\text { Promosi Penjualan } \\ \mathrm{e} & =\text { Standart error }\end{array}$

\section{E. Uji Hipotesis}

Dalam pengujian benar atau tidaknya suatu hipotesis digunakan pengujian secara statistik terhadap masing-masing koefisien regresi tersebut yang dinamakan uji taraf nyata (signifikan). Regresi berganda merupakan salah satu dari uji signifikan, masingmasing variabel dapat diketahui ada atau tidaknya dari variabel bebas secara parsial maupun secara bersamaan terhadap variabel terikat. Metode yang digunakan oleh peneliti dalam uji regresi adalah sebagai berikut : 


\section{1) Uji Parsial (Uji t)}

Uji Parsial atau Uji t digunakan untuk melihat pengaruh masing-masing variabel bebas secara parsial terhadap variabel terikat. Tingkat signifikan yang yang ditentukan dengan kriteria sebagai berikut :

a. Bila nilai signifikan $\mathrm{t}<0,05$ maka Ho akan ditolak dan Ha akan diterima, sebab terdapat pengaruh positif yang signifikan antara variabel independen terhadap variabel dependen.

b. Bila nilai signifikan $t>0,05$, maka Ho akan diterima dan Ha akan ditolak, artinya terdapat pengaruh negatif dan tidak signifikan antara satu variabel independen terhadap variabel dependen.

\section{2) Uji Simultan (Uji F)}

Menurut Ghozali (2016:96) Uji F bertujuan untuk mengetahui apakah variabel bebas (independen) secara bersama-sama berpengaruh terhadap variabel terikat (dependen). Prosedur yang digunakan dalam penelitian ini adalah sebagai berikut :

a. Dalam penelitian ini digunakan tingkat signifikan 0,05 dengan derajat bebas ( $n-k)$, dimana $\mathrm{n}$; jumlah pengamatan dan $\mathrm{k}$; jumlah variabel.

b. Kriteria keputusan :

Uji kecocokan model ditolak jika $\alpha>0,05$

Uji kecocokan model diterima jika $\alpha<0,05$

\section{Hasil dan Pembahasan}

\section{A. Uji Validitas}

Uji validitas digunakan untuk mengetahui seberapa cermat suatu instrumen atau itemitem dalam mengukur apa yang ingin diukur. Menurut Arikunto (2010: 211), validitas adalah suatu ukuran yang menunjukkan tingkat-tingkat kevalidan atau kesahihan suatu instrumen. Suatu instrumen yang valid atau sahih mempunyai validasi tinggi Sebaliknya, instrumen yang tidak valid berarti memiliki validitas rendah. Sebuah instrumen dapat dikatakan valid, apabila mampu mengukur apa yang ingin diukur dan mampu mengungkapkannya secara tepat. Tinggi rendahnya validitas instrumen menunjukkan sejauh mana data yang terkumpul tidak menyimpang dari gambaran tentang variabel yang dimaksud. Sebuah instrumen dikatakan valid apabila $r$ hitung $\geq r$ tabel, sedangkan dikatakan tidak valid apabila $r$ hitung tidak $\geq r$ tabel. Adapun kriteria pengujian untuk menerima atu menolak hipotesis adanya pernyataan yang valid atau tidak dapat dilakukan dengan :

$\mathrm{H}_{0} \rightarrow \mathrm{r}=0$, tidak terdapat data yang valid pada tingkat kepercayaan ( $\alpha$ ) $5 \%$.

$\mathrm{H}_{1} \rightarrow \mathrm{r} \neq 0$, terdapat data yang valid pada tingkat kepercayaan ( $\alpha$ ) $5 \%$.

Hipotesa nol $\left(\mathrm{H}_{0}\right)$ diterima apabila $r$ hitung $<\mathrm{r}$ tabel, demikian sebaliknya hipotesa alternatif $\left(\mathrm{H}_{1}\right)$ dterima apabila $r$ hitung $>r$ tabel . Nilai $r$ tabel yaitu sebesar 0,2146 yang didapat dari degree of freedom $(\mathrm{df})=\mathrm{n}-2$, dalam hal ini $n$ adalah jumlah sampel yaitu 84 responden. Pada penelitian ini validitas instrumen diukur dengan menggunakan SPSS 25 for Windows dengan metode korelasi product moment sehingga menghasilkan nilai masing-masing item pernyataan dengan skor item pernyataan secara keseluruhan. 
Tabel berikut menunjukkan hasil uji validitas dari empat variabel yang digunakan dalam penelitian ini. Motivasi belanja hedonis, gaya hidup berbelanja, promosi penjualan dan pembelian impulsif dengan 84 sampel responden.

Berikut adalah rincian tabel hasil uji validitas untuk setiap variabel yang digunakan dalam penelitian ini :

1) Motivasi belanja hedonis

Tabel 1. Hasil Uji Validitas Motivasi Belanja Hedonis

\begin{tabular}{|c|c|c|c|c|}
\hline Item & $\begin{array}{c}\text { Pearson } \\
\text { Corelation }\end{array}$ & Sig & $\begin{array}{c}\mathbf{r} \\
\text { Tabel }\end{array}$ & Keterangan \\
\hline $\mathrm{X} 1.1$ & 0,695 & 0,0000 & 0,214 & Valid \\
\hline $\mathrm{X} 1.2$ & 0,714 & 0,0000 & 0,214 & Valid \\
\hline $\mathrm{X} 1.3$ & 0,756 & 0,0000 & 0,214 & Valid \\
\hline $\mathrm{X} 1.4$ & 0,741 & 0,0000 & 0,214 & Valid \\
\hline $\mathrm{X} 1.5$ & 0,756 & 0,0000 & 0,214 & Valid \\
\hline $\mathrm{X} 1.6$ & 0,614 & 0,0000 & 0,214 & Valid \\
\hline $\mathrm{X} 1.7$ & 0,555 & 0,0000 & 0,214 & Valid \\
\hline
\end{tabular}

Sumber : Data primer diolah dengan SPSS 25.0, 2020

Tabel 1 menunjukkan variabel motivasi belanja hedonis mempunyai kriteria valid untuk semua item pernyataan dengan nilai signifikansi lebih kecil dari 0,05 dan nilai $r$ hitung lebih besar dari 0,214 hal ini menunjukan bahwa masing-masing peryataan pada variabel motivasi belanja hedonis dapat dinyatakan terbukti valid.

2) Variabel gaya hidup berbelanja

Tabel 2. Hasil Uji Validitas Gaya Hidup Berbelanja

\begin{tabular}{|c|c|c|r|c|}
\hline Item & $\begin{array}{r}\text { Pearson } \\
\text { Corelation }\end{array}$ & Sig & $\begin{array}{r}\mathbf{r} \\
\text { Tabel }\end{array}$ & Keterangan \\
\hline $\mathrm{X} 2.1$ & 0,573 & 0,0000 & 0,214 & Valid \\
\hline $\mathrm{X} 2.2$ & 0,644 & 0,0000 & 0,214 & Valid \\
\hline $\mathrm{X} 2.3$ & 0,739 & 0,0000 & 0,214 & Valid \\
\hline $\mathrm{X} 2.4$ & 0,712 & 0,0000 & 0,214 & Valid \\
\hline $\mathrm{X} 2.5$ & 0,700 & 0,0000 & 0,214 & Valid \\
\hline $\mathrm{X} 2.6$ & 0,730 & 0,0000 & 0,214 & Valid \\
\hline
\end{tabular}

Sumber : Data primer diolah dengan SPSS 25.0, 2020

Tabel 2 menunjukkan variabel gaya hidup berbelanja mempunyai kriteria valid untuk semua item pernyataan dengan nilai signifikansi lebih kecil dari 0,05 dan nilai $r$ hitung lebih besar dari 0,214 hal ini menunjukan bahwa masing-masing peryataan pada variabel promosi penjualan dapat dinyatakan valid terbukti. 
3) Variabel promosi penjualan

Tabel 3. Hasil Uji Validitas Promosi Penjual

\begin{tabular}{|c|c|c|r|c|}
\hline Item & $\begin{array}{c}\text { Pearson } \\
\text { Corelation }\end{array}$ & Sig & $\begin{array}{c}\mathbf{r} \\
\text { Tabel }\end{array}$ & Keterangan \\
\hline X3.1 & 0,723 & 0,0000 & 0,214 & Valid \\
\hline X3.2 & 0,864 & 0,0000 & 0,214 & Valid \\
\hline X3.3 & 0,785 & 0,0000 & 0,214 & Valid \\
\hline X3.4 & 0,746 & 0,0000 & 0,214 & Valid \\
\hline X3.5 & 0,825 & 0,0000 & 0,214 & Valid \\
\hline X3.6 & 0,669 & 0,0000 & 0,214 & Valid \\
\hline X3.7 & 0,787 & 0,0000 & 0,214 & Valid \\
\hline
\end{tabular}

Sumber : Data primer diolah dengan SPSS 25.0, 2020

Tabel 3 menunjukkan variabel promosi penjualan mempunyai kriteria valid untuk semua item pernyataan dengan nilai signifikansi lebih kecil dari 0,05 dan nilai $r$ hitung lebih besar dari 0,214 hal ini menunjukan bahwa masing-masing peryataan pada variabel promosi penjualan dapat dinyatakan valid terbukti.

4) Variabel pembelian impulsive

Tabel 4. Hasil Uji Validitas Pembelian Impulsif

\begin{tabular}{|c|c|c|c|c|}
\hline Item & $\begin{array}{c}\text { Pearson } \\
\text { Corelation }\end{array}$ & Sig & $\begin{array}{c}\mathbf{r} \\
\text { Tabel }\end{array}$ & Keterangan \\
\hline Y.1 & 0,788 & 0,0000 & 0,214 & Valid \\
\hline Y.2 & 0,799 & 0,0000 & 0,214 & Valid \\
\hline Y.3 & 0,837 & 0,0000 & 0,214 & Valid \\
\hline Y.4 & 0,585 & 0,0000 & 0,214 & Valid \\
\hline Y.5 & 0,699 & 0,0000 & 0,214 & Valid \\
\hline Y.6 & 0,789 & 0,0000 & 0,214 & Valid \\
\hline Y.7 & 0,810 & 0,0000 & 0,214 & Valid \\
\hline Y.8 & 0,735 & 0,0000 & 0,214 & Valid \\
\hline
\end{tabular}

Sumber: Data primer diolah dengan SPSS 25.0, 2020

Tabel 4 menunjukkan variabel pembelian impulsif mempunyai kriteria valid untuk semua item pernyataan dengan nilai signifikansi lebih kecil dari 0,05 dan nilai $r$ hitung lebih besar dari 0,214 hal ini menunjukan bahwa masing-masing peryataan pada variabel pembelian impulsif dapat dinyatakan valid terbukti.

\section{B. Uji Reliabilitas}

Arikunto (2010: 221), menyatakan reliabilitas menunjuk kepada satu pengertian bahwa suatu instrumen cukup dapat dipercaya untuk digunakan sebagai alat pengumpul data karena instrumen tersebut sudah baik. Uji reliabilitas dilakukan untuk menilai konsistensi dari instrumen penelitian atau untuk mengetahui sejauh mana jawaban responden yang stabil dan konsisten dari waktu ke waktu. 
Dasar suatu variabel dapat dikatakan reliabel atau tidak adalah $\alpha$ (alpha). Jika $\alpha \geq 0,6$ maka item pertanyaan tersebut dikatakan reliabel (handal), sedangkan dikatakan tidak reliabel jika nilai $\alpha$ tidak $\geq 0,6$. Dalam penelitian ini teknik pengujian reliabilitas adalah dengan menggunakan nilai koefisien cronbach alpha dan untuk mengetahui nilai reliabilitas maka peneliti menggunakan SPSS 25 for Windows. Hasil uji reliabel instrumen penelitian dapat dilihat pada tabel berikut :

Tabel 5. Uji Reliabilitas Variabel

\begin{tabular}{|c|c|c|c|}
\hline Variabel & $\begin{array}{c}\text { Cronbach's } \\
\text { Alpha }\end{array}$ & $\begin{array}{c}\text { N of } \\
\text { items }\end{array}$ & Keterangan \\
\hline Motivasi belanja hedonis & 0,802 & 7 & Reliabel \\
\hline Gaya hidup berbelanja & 0,767 & 6 & Reliabel \\
\hline Promosi penjualan & 0,886 & 7 & Reliabel \\
\hline Perilaku pembelian impulsif & 0,893 & 8 & Reliabel \\
\hline
\end{tabular}

Sumber : Data primer yang telah diolah 2020

\section{Hipotesis I atau Simultan (Uji F)}

Pengujian Uji F digunakan untuk mengetahui apakah semua variabel bebas yang dimasukkan dalam satu model secara keseluruhan mempunyai pengaruh terhadap variabel terikat. Adapun hipotesis simultan dalam penelitian ini adalah :

1) HO : tidak terdapat pengaruh secara simultan, antara variabel motivasi belanja hedonis, gaya hidup berbelanja dan promosi penjualan terhadap pembelian impulsif pada konsumen Shopee ID.

2) H1 : terdapat pengaruh secara simultan, antara variabel motivasi belanja hedonis, gaya hidup berbelanja dan promosi penjualan terhadap pembelian impulsif pada konsumen Shopee ID.

Pengujian dilakukan dengan menggunakan nilai signifikansi pada tabel ANOVA. Batas nilai signifikansi yang digunakan adalah 0,05 . Jika nilai signifikansi kurang dari $(<) 0,05$, maka HO ditolak dan H1 diterima. Sedangkan jika nilai signifikansi lebih dari (>) 0,05 maka dianggap tidak signifikan sehingga $\mathrm{H} 0$ diterima dan $\mathrm{H} 1$ ditolak.

Tabel 6 . Hasil Uji F

ANOVA $^{\mathrm{a}}$

\begin{tabular}{|l|l|r|r|r|c|c|}
\hline \multicolumn{2}{|c|}{ Model } & Sum of Squares & \multicolumn{1}{c|}{ df } & Mean Square & $\mathrm{F}$ & \multicolumn{1}{c|}{ Sig. } \\
\hline \multirow{2}{*}{1} & Regression & 1440.476 & 3 & 480.159 & 30.110 & $.000^{\mathrm{b}}$ \\
\cline { 2 - 7 } & Residual & 1275.762 & 80 & 15.947 & & \\
\cline { 2 - 7 } & Total & 2716.238 & 83 & & & \\
\hline
\end{tabular}

Sumber : Data primer diolah, 2020

Berdasarkan Tabel 6 diketahui nilai sig. $F$ hitung sebesar 0,00. Karena nilai signifikansi F kurang dari 0.05 , maka model analisis regresi adalah signifikan. Hal ini berarti $\mathrm{HO}$ ditolak dan $\mathrm{H} 1$ diterima sehingga dapat disimpulkan bahwa variabel bebas motivasi belanja hedonis 
(X1), gaya hidup berbelanja (X2) dan promosi penjualan (X3), secara simultan atau bersamasama berpengaruh terhadap pembelian impulsif pada konsumen Shopee ID.

\section{Hipotesis II atau Parsial (Uji t)}

Uji t digunakan untuk mengetahui apakah masing-masing variabel bebas secara parsial mempunyai pengaruh yang signifikan terhadap variabel terikat. Adapun hipotesis secara parsial dalam penelitian ini adalah :

1) Ha1 : terdapat pengaruh secara parsial, antara variabel motivasi belanja hedonis terhadap pembelian impulsif pada konsumen Shopee ID

2) Ha2 : terdapat pengaruh secara parsial, antara variabel gaya hidup berbelanja terhadap pembelian impulsif pada konsumen Shopee ID

3) Ha3 : terdapat pengaruh secara parsial, antara variabel promosi penjualan terhadap pembelian impulsif pada konsumen Shopee ID.

Pengujian dilakukan dengan melihat nilai $\mathrm{t}$ hitung dan nilai signifikansi pada tabel koefisien regresi. Selain itu juga dengan membandingkan antara nilai t hitung dengan $t$ tabel. Jika t hitung lebih besar ( $>$ ) dari t tabel maka hasilnya signifikan dan berarti $\mathrm{HO}$ ditolak dan Ha diterima. Sedangkan jika t hitung kurang dari $(<)$ t tabel maka hasilnya tidak signifikan dan berarti HO diteima dan Ha ditolak.

Tabel 7. Pengujuan Hipotesis Penelitian

\begin{tabular}{|c|c|c|c|c|c|c|c|c|}
\hline \multirow{2}{*}{\multicolumn{2}{|c|}{ Model }} & \multicolumn{2}{|c|}{$\begin{array}{l}\text { Unstandardized } \\
\text { Coefficients }\end{array}$} & \multirow{2}{*}{$\begin{array}{c}\text { Standardized } \\
\text { Coefficients }\end{array}$} & \multirow[b]{2}{*}{$\mathrm{t}$} & \multirow[b]{2}{*}{ Sig. } & \multicolumn{2}{|c|}{ Collinearity Statistics } \\
\hline & & B & Std. Error & & & & Tolerance & VIF \\
\hline \multirow[t]{4}{*}{1} & (Constant) & $-1,603$ & 3,408 & & $-0,470$ & 0,639 & & \\
\hline & $\begin{array}{l}\text { Motivasi } \\
\text { Belanja } \\
\text { Hedonis }\end{array}$ & 0,423 & 0,152 & 0,297 & 2,783 & 0,007 & 0,517 & 1,935 \\
\hline & $\begin{array}{l}\text { Gaya Hidup } \\
\text { Berbelanja }\end{array}$ & 0,388 & 0,177 & 0,243 & 2,187 & 0,032 & 0,476 & 2,100 \\
\hline & $\begin{array}{l}\text { Promosi } \\
\text { Penjualan }\end{array}$ & 0,362 & 0,164 & 0,293 & 2,205 & 0,030 & 0,332 & 3,015 \\
\hline
\end{tabular}

Sumber : Data primer diolah, 2020

Berdasarkan data pada Tabel 7 diperoleh hasil sebagai berikut :

1) Nilai $t$ tes antara $X 1$ (motivasi belanja hedonis) dengan $Y$ (pembelian impulsif) menunjukkan $t=2,783$ dengan probabilitas sebesar 0,007 . Nilai sig $t(0,007)$ lebih kecil dari nilai $\alpha=0.05$, maka pengaruh X1 (motivasi belanja hedonis) terhadap pembelian impulsif adalah signifikan. Hal ini berarti $\mathrm{HO}$ ditolak dan $\mathrm{H} 1$ diterima sehingga dapat diasumsikan bahwa variabel motivasi belanja hedonis secara signifikan mempengaruhi pembelian impulsif.

2) Nilai t tes antara $X 2$ (gaya hidup berbelanja) dengan $Y$ (pembelian impulsif) menunjukkan thitung $=2,187$ dengan probabilitas sebesar 0,032 . Nilai sig $t(0,032)$ lebih kecil dari nilai $\alpha=0.05$, maka pengaruh $\mathrm{X} 2$ (gaya hidup berbelanja) terhadap pembelian impulsif adalah signifikan. Hal ini berarti $\mathrm{HO}$ ditolak dan $\mathrm{H} 1$ diterima sehingga dapat diasumsikan bahwa variabel gaya hidup berbelanja secara signifikan mempengaruhi pembelian impulsif.

3) Nilai $t$ tes antara $X 3$ (promosi penjualan) dengan $Y$ (pembelian impulsif) menunjukkan $t$ hitung $=2,205$ dengan probabilitas sebesar 0,030 . Nilai sig t $(0,030)$ lebih kecil dari nilai 
$\alpha=0.05$, maka pengaruh X3 (Promosi penjualan) terhadap pembelian adalah signifikan. $\mathrm{Hal}$ ini berarti $\mathrm{HO}$ ditolak dan $\mathrm{H} 1$ diterima sehingga dapat diasumsikan bahwa variabel promosi penjualan secara signifikan mempengaruhi pembelian implusif.

\section{E. Hipotesis III (Variabel Dominan)}

Untuk mengetahui variabel independen mana yang paling dominan dan memiliki pengaruh yang paling besar terhadap variabel dependen dapat dilihat dari nilai koefisien beta dan nilai t hitung yang paling besar. Adapun hipotesis yang sebelumnya telah dibuat oleh peneliti adalah :

$\mathrm{Ha}$ : variabel motivasi belanja hedonis merupakan variabel yang paling dominan mempengaruhi pembelian impulsif.

Berdasarkan hasil penelitian pada tabel 7 diatas, diketahui bahwa dari ketiga variabel bebas, hanya variabel motivasi belanja hedonis yang memliki nilai koefisien beta paling besar yaitu sebesar 0,297. Maka dapat diasumsikan variabel motivasi belanja hedonis secara paling dominan mempengaruhi pembelian impulsif, sehingga dapat disimpulkan bahwa hipotesis (Ha) diterima.

\section{SIMPULAN}

Berdasarkan penelitian yang telah peneliti lakukan, dapat diperoleh kesimpulan sebagai berikut :

1) Berdasarkan hasil diketahui bahwa pengaruh motivasi belanja hedonis, gaya hidup berbelanja dan promosi penjualan terhadap pembelian impulsif pada konsumen Shopee ID secara simultan signifikan $(0,00)$.

2) Berdasarkan hasil secara parsial diketahui bahwa pengaruh motivasi belanja hedonis, gaya hidup berbelanja dan promosi penjualan terhadap pembelian impulsif pada konsumen Shopee ID yaitu signifikan X1 $(0,00)$, X2 $(0,03)$, dan X3 $(0,03)$.

3) Hasil berdasarkan pada pengaruh motivasi belanja hedonis, gaya hidup berbelanja dan promosi penjualan terhadap pembelian impulsif pada konsumen Shopee ID yang paling dominan adalah motivasi belanja hedonis.

4) Diketahui pengaruh yang paling dominan pada motivasi belanja hedonis dipengaruhi oleh beberapa indikator antara lain : petualangan, sosial, ide, nilai dan status.

\section{SARAN}

\section{A. Bagi Perusahaan}

1) Dilihat dari hasil variabel motivasi belanja hedonis, gaya hidup berbelanja, promosi penjualan dan pembelian impulsif berdasarkan kuesioner dari responden rata-rata hasilnya cukup baik. Perusahaan perlu meningkatkan lebih baik lagi untuk pembelian impulsif konsumen Shopee ID dimasa yang akan datang.

2) Berdasarkan penelitian ini, perlu konsisten dan dipertahankan pada stimulus pada motivasi belanja hedonis yang dipengaruhi oleh indikator antara lain : petualangan, sosial, ide, nilai dan status.

\section{B. Bagi Peneliti}

1) Bagi peneliti yang akan meneliti pada Shopee ID, bisa lebih mengembangkan penelitian ini menggunakan intervening. 


\section{DAFTAR PUSTAKA}

Aziz, \& V, A, R.(2015).'Pengaruh Persepsi Risiko dan Gaya Hidup Terhadap Keputusan Pembelian Pakaian Secara Online Melalui Blackberry Messenger “. eJournal Psikologi, 5.

Belch, G. and Belch, M. (2015) Advertising and promotion: An Integrated.

Betty R. Jackson. (2004) "Audit Information Dissemination Taxpayer Communication and Compliance: An Experimental Approach.” IRS Research Conference, Washington, DC.

Cobb, J, C \& Hoyer W. D. (1986). Planned Versus Impulse Purchase Behaviour, Journal of Retailing, 62 (4).

G.Leon, Schiffman dan Lazar L Kanuk. (2008). Perilaku Konsumen. Edisi Ketujuh.

Kotler, Philip,(2007), Manajemen Pemasaran, Jilid 2, Edisi 12, PT Indeks., New Jersey.

Kotler, dan Keller.(2012) “Manajemen Pemasaran”, Erlangga, Jakarta.

Kosyu, D, A., Hidayat, K, \& Abdillah, Y., (2014). Pengaruh Hedonic Shopping Motives Terhadap Shopping Lifestyle dan Impulse Buying ( Survey Pada Pelanggan Outlet Stradivarus di Galaxy Mall Surabaya). Jurnal Administrasi Bisnis, 14(2),pp, 1-7.

Lestari, L, P dan Oetomo, H. W. (2014). Pengaruh Hedonic Shopping Value Terhadap Impulse Buying Melalui Positive Emoticon Customer Flashyshop. Jurnal Ilmu dan Riset Manajemen. Vol 3, No 78:1-7.

Levy, M and Weitz, B.A.( 2009). Retailing Manajemen. 7Ed. New York: Mc Graw Hill.

Paramita, Adiska O., Zainul Arifin, dan Sunarti.(2014). Pengaruh nilai belanja hedonis terhadap pembelian impulsif pada toko online dengan emosi positif sebagai variabel perantara. Jurnal Administrasi Vol.8 No.2

Park, Eun Joo., Kim, Eun Young., dan Forney, Judith Cardona.(2006). "A Structural Model of Fashion-Oriented Impulse Buying Behavior", Journal of Fashion Marketing and Management.

Peter and Olson. (2013). Perilaku Konsumen dan Strategi Pemasaran. Jilid 1.

Scarpi.D.(2006). Fashion Stores Between Fun and Usefulness. Journal of Fashion Marketing and Management,(10) 1:7-24

Semuel, H.(2005). Respon Lingkungan Berbelanja Sebagai Stimulus Pembelian. Jurnal Manajemen dan Kewirausahaan. Vol, No.2

Utami, B., (2016), Pengaruh Nilai Belanja Hedonik Terhadap Impulse Buying Dengan Emosi Positif Sebagai Variabel Perantara. Skripsi. Jurusan Manajemen FE UNY

Utami, Christina Whidya (2010). Manajemen Ritel. Salemba Empat . Jakarta

Utami, Christina Whidya.(2012)."Manajemen Ritel: Strategi dan Implementasi Ritel modern". Salemba Empat. Jakarta 
https://databoks.katadata.co.id/datapublish/2019/10/10tren-pengguna-e-commerce-2017-2023

http://.techinasia.com/persaingan-ecommerce-indonesia-q3-2019

https://www.cnbcindonesia.com/tech/20190311101823-37-59800/wow-transaksi-e-commerceri-2018-capai-rp-77-t-lompat-151

https://zonautara.com/2019/05/16/pengguna-internet-di-indonesia-terus-tumbuh/ 